\title{
MENINGKATKAN KEMAMPUAN KOMUNIKASI MATEMATIS SISWA SMP UNTUK MENGETAHUI PENGARUH PENDEKATAN KONTEKSTUAL
}

\author{
Siti Jenab ${ }^{1}$, Mita Islamiyati ${ }^{2}$, Ratna Sariningsih ${ }^{3}$ \\ 1,2,3 IKIP Siliwangi, Jalan Terusan Jenderal Soedirman Cimahi \\ 1jejesiti@gmail.com²mitabisa@gmail.com ${ }^{3}$ ratnasari_ning@ymail.com
}

\begin{abstract}
This study aims to determine the improvement of mathematical communication skills of junior high school students from the influence of contextual approach. This research takes the form of a posttest pretest design that compares the influence of a contextual approach with a conventional approach. This study has a population that is all students of SMP class VII in Cianjur District while the sample is a student of class VII SMP Plus Al-Ittihad Cianjur. The samples were taken at random into experimental groups and control groups. Based on the data in the field, it can be concluded that the effect of improving mathematical communication ability of junior high school students who gain learning using contextual approach is better than conventional learning. Therefore, the effect of improving learning with contextual approach is much better while conventional learning is still very less.
\end{abstract}

Keywords: Contextual, Mathematical Communication

\begin{abstract}
Abstrak
Penelitian ini bertujuan untuk mengetahui peningkatan kemampuan komunikasi matematis siswa SMP dari pengaruh pendekatan kontekstual. Penelitian ini berbentuk desain pretest postest yang membandingkan pengaruh pendekatan kontekstual dengan pendekatan konvensional. Penelitian ini mempunyai populasi yaitu seluruh siswa SMP kelas VII se- Kabupaten Cianjur sedangkan sampelnya yaitu siswa kelas VII SMP Plus Al-Ittihad Cianjur. Dari sampel tersebut di ambil secara acak yang menjadi kelompok eksperimen dan kelompok kontrol. Berdasarkan data di lapangan di peroleh kesimpulan bahwa pengaruh peningkatan kemampuan komunikasi matematis siswa SMP yang memperoleh pembelajaran menggunakan pendekatan kontekstual lebih baik daripada pembelajaran konvensional. Maka dari itu, pengaruh peningkatan pembelajaran dengan pendekatan kontekstual jauh lebih bagus sedangkan pembelajaran konvensional masih sangat kurang.
\end{abstract}

Kata Kunci: Kontekstual, Komunikasi Matematis

Cara Mengutip: Jenab, S., Islamiyati, M., Sariningsih, R., (2018). Meningkatkan Kemampuan Komunikasi Matematis Siswa SMP untuk Mengetahui Pengaruh Pendekatan Kontekstual. JPMI - Jurnal Pembelajaran Matematika Inovatif, 1 (5), 941-948.

\section{PENDAHULUAN}

Matematika merupakan ilmu dasar yang harus dikuasai oleh setiap manusia serta mempunyai peranan sangat penting untuk mengetahui pencapaian keberhasilan dalam berbagai bidang. Pernyataan tersebut dilatarbelakangi oleh pemahaman matematika akan menjadi wadah yang tepat untuk mempelajari mata pelajaran lainnya, baik pada jenjang pendidikan yang sama maupun pada pendidikan yang lebih tinggi lagi. 
Bagian terbesar dari matematika yang dipelajari oleh siswa di sekolah tidak diperoleh melalui eksplorasi matematik, namun melalui pemberitahuan. Selanjutnya bahwa situasi pembelajaran yang terjadi di kelas menjadikan siswa pasif. Dan juga pada waktu pembelajaran di dalam kelas, pembelajaran matematika didominasi dengan cara pembelajaran biasa yang terpusat pada guru. Komunikasi akan membantu siswa mengembangkan bagaimana berpikir dan bagaimana menerima pegetahuan yang diinginkan. Namun demikian, umumnya pada pembelajaran matematika, kurang diberikan peluang bagi siswa untuk mengkomunikasikan materi matematika yang sedang siswa pelajari agar dapat menginterpretasikan ke dalam bahasa lisan dan tulisan yang mudah dipahami. Pembelajaran lebih terfokus untuk mendapatkan jawaban dan menyerahkan jawaban tersebut kepada guru untuk mengetahui apakah jawabannya benar atau salah. Oleh karena itu, setiap pelajaran matematika yang disampaikan di kelas lebih banyak bertumpu pada hal-hal yang bersifat hafalan. Memang memungkinkan siswa untuk memperoleh nilai yang cukup tinggi, namun siswa bukanlah pemikir yang bagus di kelas dan akan kesulitan untuk menyelesaikan masalah-masalah matematika, terutama untuk soal-soal pemecahan masalah (Elida, 2012)

Kemampuan komunikasi matematika sangat penting dimiliki oleh siswa, karena komunikasi matematik merupakan : 1) kekuatan pusat untuk siswa pada rumusan konsep serta starategi matematik, 2) modal kesuksesan untuk siswa pada pendekatan serta pemecahan dalam eksplorasi dan investigasi matematik, 3) tempat untuk siswa dalam berinteraksi dengan temannya untuk memperoleh informasi, bertukar fikiran dan penemuan, menilai dan memperkuat ide untuk menguatkan orang lain.

Kemampuan komunikasi matematis menjadi salah satu kegiatan sosial agar terus dikembangkan oleh para siswa. Kemudian komunikasi juga menjadi peranan penting pada "Professional Teaching Standards" sebab mengajar adalah mengkomunikasikan. Gagasan dokumen itu adalah sampel bagaimana kita menghubungkan apa yang guru pahami terhadap belajar siswa dengan berbagai peserta. Hal ini merupakan hubungan antara tujuan assessmen dengan apa dan bagaimana kita berkomunikasi (Husna1, M. Ikhsan2, 2013).

Komunikasi merupakan esesensi dari mengajar, assessing, serta belajar matematika. Apabila mengajar, guru membutuhkan aktivitas-aktivitas, misalnya kita perlu untuk mendengarkan apa yang siswa mengerti, untuk mereka mengetahui, dan untuk apa mereka berfikir tentang matematika dan belajar matematika (Umar, 2012).

Pembelajaran yang inovatif sangat bagus diterapkan dalam pembelajaran matematika salah satu pembelajaran inovatif tersebut adalah pembelajaran dengan menggunakan pendekatan kontekstual. Pendekatan kontekstual merupakan suatu alternatif pembelajaran yang bisa menciptakan kondisi dan situasi kelas yang kondusif dan lebih memberdayakan siswa. Kontruktivisme yang berada pada pendekatan kontekstual mewajibkan siswa agar membangun/mengkonstruksi diri mereka tutamanya pada unsur kognitif. Sehingga, saat anak mampu mengkonstruksi dirinya maka akan muncul dalam diri siswa untuk mengatur diri siswa dalam belajar, menggabungkan kemampuan metakognisi, motivasi dan perilaku aktif. Untuk menyelesaikan masalah diperlukan kemampuan untuk mengkonstruksi pengetahuan siswa. Disaat siswa mendapatkan masala, maka pada saat itu siswa dituntut untuk berusaha membangun dirinya dalam menyelesaikan masalah atau persoalan tersebut. Oleh karena itu, dengan pembelajaran kontekstual hasil pembelajaran yang diharapkan lebih berarti dan proses pembelajaran berlangsung secara alamiah, jadi dalam pembelajaran ini proses lebih diprioritaskan daripada hasil (Sariningsih, 2014). 
Memperhatikan karakteristik komunikasi matematis, karakteristik pendekatan kontekstual, maka pendekatan tersebut memungkinkan dapat meningkatkan pengaruh kemampuan komunikasi matematis siswa. Sehingga penulis tertarik untuk melakukan penelitian dengan judul "Meningkatan Kemampuan Komunikasi Matematis Siswa SMP untuk Mengetahui Pengaruh Pendekatan Kontekstual ".

Kemampuan komunikasi merupakan kemampuan berpikir kritis yang penting ditumbuh kembangkan. Pentingnya komunikasi matematis di kembangkan dalam pembelajaran matematika seiring dengan hasil survey yang di lakukan oleh Program for Internasional Student Asesment ( PISA) tahun 2009 pada kemampuan membaca, matematika serta IPTEK, rating Indonesia berada di posisi ke-57 dari negara yang lain untuk bidang matematika. survey yang di lakukan PISA menilai kemampuan matematika siswa dalam memecahkan masalah, yang meliputi mengenali dan menganalisis masalah, memformulasikan alasan dan mengkomunikasikan gagasan yang dimilikinya kepada orang lain.

Matematika merupakan suatu bahasa sangat dibutuhkan untuk disampaikan secara lisan ataupun tulisan maka informasi yang di sampaikan dapat diketahui dan dipahami oleh orang lain. Seperti yang dikemukakan oleh Cockroft (Anggraeni \& Sumarno, 2013), 'We believe that all these percepcions of the usefulness of mathematics arise from the fact that mathematics provides a means of communication which is powerful, concise, and unambiguous'. Pernyataan ini berisi tentang pentingnya alat komuniaksi yang cukup kuat, teliti, dan mudah di pahami oleh siswa.

Kemampuan komunikasi sangat perlu di hadirkan secara intensif agar siswa terlibat aktif dalam pembelajaran dan menghilangkan kesan bahwa matematika merupakan pelajran yang asing dan menakutkan. Kemampuan komunikasi juga sangat penting karena matematika pada dasarnya adalah bahasa yang syarat debgan notasu dan istilah hingga konsep yang terbentuk dan di pahami serta dimanipulasi oleh siswa.

Menurut Fatimah (2009) ada dua argumen tentang alasan mengapa komunikasi matematik dibutuhkan, yaitu: (1) mathematics as language, maknanya matematika bukan hanya sekedar alat bantu untuk berpikir. Matematika berperan untuk menemukan pola, memecahkan masalah, namun demikian, matematika merupakan an invaluable for communicating a variety of ideas, precisely, and succinctly dan (2) mathematics is learning as social activity, artinya sebagai kegiatan sosial dalam pembelajaran matematika,contohnya seperti interaksi antar siswa, interaksi guru dengan para siswa, komunikasi guru dengan para siswa adalah bagian penting terhadap pembelajaran matematika pada upaya membimbing siswa untuk memahami konsep atau mencari solusi untuk memecahkan masalah.

Kemampuan Komunikasi Matematik tercantum dalam kurikulum matematika sekolah menengah. Komponen tujuan pembelajaran matematika yaitu mengkomunikasikan gagasan dengan simbol, tabel, diagram atau ekspresi matematika untuk memperjelas keadaan atau masalah, dan mempunyai sikap menghargai kegunaan matematika dalam kehidupan, sikap rasa ingin tahu, perhatian, dan minat dalam mempelajari matematika, selain itu sikap ulet dan percaya diri dalam pemecahan masalah (Choridah, 2013).

Indikator komunikasi matematik yang meliputi kemampuan : Menghubungkan benda nyata, diagram, dan gambar ke dalam ide matematika, menjelaskan ide, situasi, serta hubungan matematik, baik secara lisan ataupun tulisan oleh benda nyata, gambar, grafik , serta aljabar yang menyatakan peristiwa sehari-hari ke dalam bahasa serta simbol matematika, mendengarkan, bertukar pendapat, serta menulis mengenai pembelajaran matematika, 
membaca dengan memahami presentasi matematika, menyusun konjektur, menyusun pendapat, merumuskan definisi serta generalisasi, mengungkapkan ulang paragraf matematika pada bahasa sendiri (Permana \& Sumarmo, 2007).

Pembelajaran kontekstual (contextual teaching and learning) yaitu suatu konsep belajar yang mampu membantu guru mengaitkan materi yang di sampaikan dengan kondisi nyata siswa dan membimbing siswa untuk membuat relasi antara pengetahuan yang siswa miliki dengan menerapkan pengetahuan tersebut dalam kehidupan sehari-hari (Biyarti \& Sujadi, 2013).

Sedangkan hasil penelitian Northwest Regional Education Laboratories dalam (Sariningsih, 2014) mengatakan bahwa pengajaran kontekstual sangat membawa pengaruh positif karena dapat menciptakan arti sebuah pengalaman belajar serta meningkatkan prestasi akademik siswa. Selanjutnya, pembelajaran menggunakan pendekatan konteksual secara praktis dapat peningkatan minat belajar siswa serta meningkatkan keikutsertaan siswa dengan mendukung penuh dalam memberikan peluang kepada mereka untuk mengkonstruksi pengetahuan dan menerapkan apa yang telah mereka ketahui sehingga dapat meningkatkan pemecahan masalah matematis di kehidupan sehari-hari.

Aktivitas pengajaran kontekstual yang dikembangkan adalah: a) Belajar Berbasis Masalah merupakan pembelajaran dengan memakai pendekatan kontekstual diawali dengan menghadapkan siswa kedalam permasalahan yang nyata dan menantang, supaya siswa dapat termotivasi untuk memecahkannya. Ketika siswa berhadapan dengan permasalahan itu, mereka yang menyadari bahwa hal tersebut dapat diketahui dari berbagai sudut pandang. Mereka akan mengetahui bahwa untuk memecahakan masalah matematika, mereka dituntut agar dapat mengkonstruksi pengetahuannya dengan ktiris, menghubungkan serta mengintegrasikan informasi, ide-ide serta pemahaman berbagai konsep ilmu pengetahuan yang ia miliki. b) Belajar dengan menggunkan Multi Konteks merupakan belajar dengan situasi nyata atau yang disimulasikan serta familiar, oleh sebab itu pengetahuan yang diperoleh dari sekolah dapat diaplikasikan di tempat kerja, di rumah, bahkan di lingkungan masyarakatnya. Oleh karena itu, proses belajar siswa dalam mendapatkan pengetahuan didapatkan melalui suatu pengkoordinasian yang melibatkan konteks sosial dan fisik, sehingga setting pembelajaran dapat dilakukan di dalam dan di luar kelas. c) Belajar dengan Mandiri mempunyai tiga karakteristik yaitu : (1) kesadaran dalam berpikir, (2) penggunaan suatu strategi, dan (3) mempertahankan motivasi (Sariningsih, 2014).

Pengembangan sifat belajar mandiri pada diri siswa antara lain peningkatan kesadaran akan berpikir efektif dan kemampuan mengkoreksi kebiasaan berpikir. Seseorang mempunyai peluang untuk menghubungkan keterkaitannya dalam kegiatan observasi, evaluasi, dan bertindak untuk menunjukan setiap rencana yang dibuat, strategi pilihan, dan melihat kembali/mengevaluasi tentang pekerjaan yang telah dilakukan. Hal ini mengindikasikan bahwa, dengan siswa belajar mandiri, akan dapat menjawab semua permasalahan yang dihadapinya, dengan kemampuan pemahaman matematis yang dilanjutkan sesuai dengan tahapan penyelesaian problem solving. d) Penilaian Otentik merupakan suatu penilaian yang tidak hanya mementingkan produk pembelajaran, tetapi lebih berorientasi pada proses sehingga pelaksanaan penilaian menyatu selama proses pembelajaran berlangsung. Dengan cara ini, maka setiap perkembangan peserta didik baik individu maupun kelompok akan teramati, sehingga setiap kelebihan dan kelemahan yang ditemukan akan segera dapat dimanfaatkan sebagai timbal balik bagi siswa maupun guru. e) Masyarakat Belajar merupakan kegiatan belajar mengajar siswa ketika berlangsung melibatkan suatu kelompok belajar tertentu yang dikenal sebagai masyarakat belajar (Learning Community). Dalam komunitas ini, siswa 
mempunyai peranan penting dalam proses belajar, guru bukan satu-satunya sumber belajar, peserta didik berbicara mengemukakan pendapatnya, berbagi pengalaman serta pengetahuan beserta orang lain dan bekerja sama dalam suatu kelompok kecil (4-5 orang siswa) untuk mencari solusi serta menjawab suatu permasalahan, saling berpendapat dan menghargai asumsi orang lain. Dengan demikian, dalam berlangsungnya pembelajaran, akan terjadi proses umpan balik yang aktif antara siswa dengan guru. Dengan terjadinya hubungan tersebut, maka dari itu dengan sendirinya muncul refleksi buah pemikiran siswa maupun kelompoknya, yang akhrinya akan meningkatkan pemecahan dan pemahaman masalah matematis siswa. Kemudian ada lima komponen yang wajib diperhatikan pada pembelajaran biasa, yaitu : a) Pengaktifan pengetahuan yang telah di pelajari, b) Pemerolehan pengetahuan yang belum di pelajari, c) pemahaman pengetahuan, d) mengimplementasikan pengetahuan dan pengalaman tersebut, e) refleksi pengetahuan.

Teori belajar yang menjadi landasan model pembelajaran kontekstual adalah: a) Teori Piaget, piaget mengemukakan bahwa terdapat 2 langkah yang terjadi dalam perkembangan dan pertumbuhan kognitif anak yaitu: (1) proses asimilasi, pada proses ini menyesuaikan atau mencocokan informasi baru dengan apa yang sudah diketahui bila perlu dengan mengubahnya; (2) proses accomodation yaitu siswa menyusun dan mengkonjektur ulang atau mengkoreksi apa yang sudah diketahui sebelumnya, maka informasi yang baru tersebut dapat disesuaikan. b) Teori Konstruktivisme, teori konstruktivisme menjadi landasan utama pembelajaran kontekstual. Hal ini dikarenakan dalam pembelajaran kontekstual, siswa membangun pengetahuannya secara aktif. Pada konstruktivisme, pengetahuan bukan seperangkat fakta, konsep, atau unsur yang harus diambil dan diingat. Tetapi harus mengkonstruksi pengetahuan tersebut dan memberi arti melalui pengalaman sehari-hari. c) Teori Bruner, dalam pembelajaran kontekstual, teori Bruner merupakan teori yang penting. Hal ini dikarenakan dengan pengalamannya siswa akan mencoba untuk menyesuaikan kembali struktur-struktur idenya untuk mencapai keseimbangan dalam benaknya. Hal ini sejalan dengan esensi pada pembelajaran kontekstual, yakni siswa berpartisipasi secara aktif menemukan dan mengaitkan informasi kompleks ke situasi lain (Sariningsih, 2014).

Hasil penelitian tentang KBM dengan pendekatan kontekstual yang dilaksanakan di Amerika oleh The Contextual and Consortium yang bekerjasama dengan Oregon University terhadap siswa sekolah menengah tahun 2000 (Sariningsih, 2014) menyimpulkan bahwa: 1) Tidak sedikit siswa yang menerima dan bertanggung jawab agar belajar mandiri. 2) Siswa senang untuk belajar secara interaksi sosial. 3) Semua siswa dalam belajar terbimbing, baik yang kurang maupun yang pintar. 4) Guru sangat berperan penting dalam pembelajaran dan penyusunan KBM. 5) Kelas terbuka dan siswa yang bekerjasama secara team merupakan kunci keberhasilan pembelajaran.

\section{METODE}

Studi ini dirancang dengan metode kuasi eksperimen yang bertujuan untuk menunjukan hubungan antar variabel, menguji teori, serta mencari generalisasi yang mempunyai nilai prediktif (Sugiyono, 2013). Penelitian ini juga diharapkan agar dapat meningkatkan kemampuan komunikasi matematis siswa SMP. Penelitian ini populasinya adalah seluruh siswa SMP Plus Al-Ittihad kelas VII, sedangkan sampelnya yaitu siswa kelas VII J dan VII K SMP Plus Al-Ittihad. Lalu dari sampel tersebut ditetapkan secara acak yang menjadi kelas kontrol dan kelas eksperimen. Tes kemampuan pemahaman matematis siswa masing-masing disusun berpedoman pada karakteristik kemampuan komunikasi matematis penyususunan tes yang 
bagus. Data akan dianalisis menggunakan uji statistik t, dan uji dengan statistik $x^{2}$ (untuk uji asosiasi antar variabel).

\section{HASIL DAN PEMBAHASAN}

\section{Hasil}

Berikut ini disajikan hasil temuan mengenai kemampuan komunikasi matematis siswa seperti tersaji pada Tabel 1.

Tabel 1. Komunikasi Matematis

\begin{tabular}{ccccccc}
\hline \multirow{2}{*}{$\begin{array}{c}\text { KEMAMPUAN } \\
\text { MATEMATIS }\end{array}$} & \multicolumn{2}{c}{$\begin{array}{c}\text { Kelas Eksperimen } \\
(\mathbf{n = 3 1})\end{array}$} & \multicolumn{2}{c}{$\begin{array}{c}\text { Kelas Kontrol } \\
(\mathbf{n}=\mathbf{3 0})\end{array}$} \\
\cline { 2 - 7 } & Pretes & postes & gain & Pretes & Postes & gain \\
\hline & $\mathbf{1 , 8 0}$ & $\mathbf{9 , 9 5}$ & & 1,75 & $\mathbf{5 , 4 6}$ & \\
& $\mathrm{s}$ & $\mathbf{3 , 0 4}$ & $\mathbf{1 , 8 0}$ & $\mathbf{1 . 2 5}$ & $\mathbf{2 , 2 4}$ & \\
\hline
\end{tabular}

Setelah dilakukan uji normalitas sebaran data kemampuan komunikasi matematis dan peningkatannya diperoleh bahwa data tidak berdistribusi normal. Berdasarkan temuan tersebut, maka pengujian perbedaan rerata kemampuan komunikasi matematis dilakukan dengan uji Mann Withney dengan pengujian hipotesisnya menurut (Uyanto, 2009) :

$\mathrm{H}_{0}$ : Kemampuan komunikasi matematis siswa SMP yang pembelajarannnya menggunakan pendekatan kontekstual tidak lebih baik atau sama dengan yang menggunakan pembelajaran biasa.

$\mathrm{H}_{1}$ : Kemampuan komunikasi matematis siswa SMP yang pembelajarannya menggunakan pendekatan kontekstual lebih baik daripada yang menggunakan pembelajaran biasa.

Kriteria pengujiannya sebagai berikut:

a. Jika nilai signifikansi $\geq 0,05$ maka $\mathrm{H} 0$ diterima.

b. Jika nilai signifikansi $<0,05$ maka $\mathrm{H} 0$ ditolak.

Tabel 2. Uji Mann Withney Pembelajaran Kontekstual dengan Pembelajaran Konvensional

\begin{tabular}{lcl}
\hline KEMAMPUAN & SIG. & \multicolumn{3}{c}{ INTERPRETASI } \\
\hline $\begin{array}{l}\text { Komunikasi } \\
\text { matematis }\end{array}$ & 0.000 & $\begin{array}{l}\text { Komunikasi matematis siswa, yang pembelajarannya } \\
\text { menggunakan kontekstual lebih baik daripada cara pembelajaran } \\
\text { biasa dengan taraf signifikansinya 5\% }\end{array}$ \\
\hline $\begin{array}{l}\text { Uji Gain } \\
\text { kemampuan }\end{array}$ & 0.000 & $\begin{array}{l}\text { Peningkatan kemampuan komunikasi matematis siswa, yang } \\
\text { pembelajarannya menggunakan pendekatan kontekstual lebih }\end{array}$ \\
komunikasi & & $\begin{array}{l}\text { baik daripada cara pembelajaran biasa dengan taraf } \\
\text { signifikansinya 5\% }\end{array}$ \\
Matematis &
\end{tabular}

Berdasarkan hasil analisis pada Tabel 2, diperoleh nilai signifikansinya sebesar 0,000 artinya nilai siginifikansi dengan menggunakan uji Mann Whitney $<0,05$ maka $\mathrm{H}_{0}$ ditolak, dengan demikian kemampuan komunikasi matematis siswa yang menggunakan pembelajaran kontekstual lebihbaik daripada siswa yang pembelajarannya menggunakan pembelajaran biasa.

\section{Pembahasan}

Berdasarkan hasil analisis di atas menunjukkan bahwa skor rata-rata pretes kelas kontrol dan 
kelas eksperimen tidak jauh berbeda dengan kata lain kemampuan awal komunikasi matematik siswa SMP yang pembelajarannya menggunakan pendekatan kontekstual dengan yang menggunakan pembelajaran biasa tidak terdapat perbedaan yang jauh berbeda.

Adapun skor rata-rata postes yang berdasar pada hasil analisis data di atas menunjukkan bahwa kelas eksperimen lebih unggul daripada kelas kontrol, dengan kata lain pencapaian kemampuan komunikasi matematis siswa SMP yang pembelajarannya menggunakan pendekatan kontekstual lebihbaik daripada yang menggunakan pembelajaran biasa.

Begitupula dengan skor rata-rata gain menunjukkan skor gain kelas eksperimen lebih besar daripada kelas kontrol, dengan kata lain peningkatan kemampuan komunikasi matematis siswa SMP yang pembelajarannya menggunakan pendekatan kontekstual lebihbaik daripada yang menggunakan pembelajaran biasa.

Di dalam kelas, para siswa yang pembelajarannya menggunakan pendekatan kontekstual para siswa belajar untuk menemukan makna dalam pelajaran mereka dengan cara menghubungkan materi akademik dengan konteks kehidupan keseharian mereka. Keterkaitan yang mengarah pada makna ini adalah bagian terpenting dalam pembelajaran kontekstual, karena dengan makna akan memberi alasan mereka untuk belajar sehingga kesungguhan untuk belajar semakin baik. Seperti pada hasil penelitian Setiawan \& Harta (2014) dalam proses pembelajaran, siswa juga akan membuat hubungan-hubungan penting yang menghasilkan makna dengan melaksanakan pembelajaran yang di dalamnya terdapat komponen-komponen CTL.

Berdasarkan hasil pembahasan tersebut dapat diketahui bahwa kemampuan komunikasi matematis siswa SMP yang pembelajarannya menggunakan pendekatan kontekstual lebih baik daripada yang menggunakan pembelajaran biasa. Pendekatan kontekstual juga dapat meningkatkan kemampuan komunikasi matematis siswa, sejalan dengan hasil penelitian menurut Senjayawati (2015) yang menyatakan bahwa peningkatan kemampuan komunikasi matematik siswa yang memperoleh pembelajaran dengan pendekatan kontekstual lebih baik daripada yang memperoleh pembelajaran konvensional. Hal tersebut dikarenakan pendekatan kontekstual mampu melatih siswa membuat relasi antara pengetahuan yang siswa miliki dengan menerapkan pengetahuan tersebut dalam kehidupan sehari-hari.

\section{KESIMPULAN}

Berdasarkan analisis data dan pembahasan, maka kesimpulannya adalah:

1).Pencapaian kemampuan komunikasi matematis siswa ketika berlangsungnya pembelajaran, dengan pendekatan kontekstual lebih baik daripada menggunakan pendekatan biasa. Pencapaian siswa yang medapatkan pembelajaran dengan menggunakan pendekatan kontekstual memperoleh pencapaian yang baik sedangkan siswa yang pembelajarannya konvensional masih sangat kurang.

2).Peningkatan kemampuan komunikasi matematis siswa ketika berlangsungnya pembelajaran, dengan pendekatan kontekstual lebih baik daripada pendekatan biasa. Pencapaian siswa yang mendapatkan pembelajaran dengan menggunakan pendekatan kontekstual memperoleh pencapaian yang baik sedangkan siswa yang pembelajarannya konvensional masih sangat kurang.

\section{DAFTAR PUSTAKA}

Anggraeni, D., \& Sumarno, U. (2013). Meningkatkan Kemampuan Pemahaman Dan 
Komunikasi Matematik Siswa Smk Melalui Pendekatan Kontekstual Dan Strategi Formulate-Share-Listen-Create (Fslc). Jurnal Ilmiah Program Studi Matematika STKIP Siliwangi Bandung, 2(1), 1-12.

Biyarti, T., \& Sujadi, I. (2013). Eksperimentasi Model Pembelajaran Think Pair Share Dengan Pendekatan Kontekstual Pada Materi Logis Siswa Kelas X Pada Sekolah Menengah Atas Di Kabupaten Cilacap Tahun Pelajaran 2012 / 2013. Jurnal Elektronik Pembelajaran Matematika, 1(7), 690-699.

Choridah, D. T. (2013). Peran Pembelajaran Berbasis Masalah Untuk Meningkatkan Kemampuan Komunikasi Dan Berpikir Kreatif Serta Disposisi Matematis Siswa Sma. Infinity Jurnal Ilmiah Program Studi Matematika STKIP Siliwangi Bandung, 2(2), 1-9. Retrieved from http://download.portalgaruda.org/article.php?article=133698\&val=5628\&title=

Elida, N. (2012). Meningkatkan kemampuan komunikasi matematik siswa sekolah menengah pertama melalui pembelajaran think-talk-write (ttw). Infinity Jurnal Ilmiah Program Studi Matematika STKIP Siliwangi Bandung, Vol 1, No.2, September 2012, 1(2), 178-185.

Fatimah, F. (2009). Kemampuan komunikasi matematis dan pemecahan masalah melalui problem based-learning. Jurnal Penelitian Dan Evaluasi Pendidikan, 249-259.

Husna1, M. Ikhsan2, S. F. (2013). PENINGKATAN KEMAMPUAN PEMECAHAN MASALAH DAN KOMUNIKASI MATEMATIS SISWA SEKOLAH MENENGAH PERTAMA MELALUI MODEL PEMBELAJARAN KOOPERATIF TIPE THINKPAIR-SHARE (TPS). Jurnal Peluang, Volume 1, Nomor 2, April 2013, ISSN: 2302-5158, 1(April), 81-92.

Permana, Y., \& Sumarmo, U. (2007). Mengembangkan Kemampuan Penalaran dan Koneksi Matematik Siwa SMA Melalui Pembelajaran Berbasis Masalah. Educationist, I(2), 116123.

Sariningsih, R. (2014). Pendekatan kontekstual untuk meningkatkan kemampuan pemahaman matematis siswa smp. Ilmiah Program Studi Matematika STKIP Siliwangi Bandung, 3(2), 150-163. https://doi.org/https://doi.org/10.22460/infinity.v3i2.60

Senjayawati, E. (2015). Penerapan Pendekatan Kontekstual untuk Meningkatkan Kemampuan Komunikasi Matematik Siswa SMK di Kota Cimahi. Jurnal Ilmiah STKIP Siliwangi Bandung 33, 9, 33-39.

Setiawan, R. H., \& Harta, I. (2014). Pengaruh pendekatan open-ended dan pendekatan kontekstual terhadap kemampuan pemecahan masalah dan sikap siswa terhadap matematika. Jurnal Riset Pendidikan Matematika, 1(2), 241. https://doi.org/10.21831/jrpm.v1i2.2679

Umar, W. (2012). Membangun kemampuan komunikasi matematis dalam pembelajaran matematika. Jurnal Ilmiah Program Studi Matematika STKIP Siliwangi Bandung, Vol 1, No.1, Februari 2012, 1(1). 